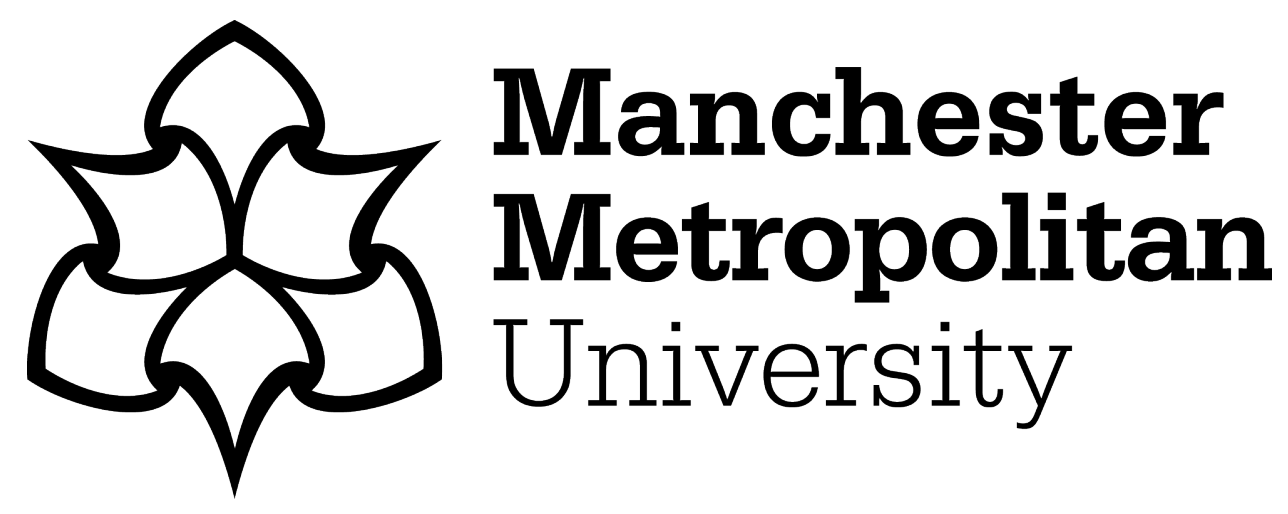

Leal Filho, W, Pallant, E, Enete, A, Richter, B and Brandli, LL (2018) Planning and implementing sustainability in higher education institutions: an overview of the difficulties and potentials. International Journal of Sustainable Development and World Ecology, 25 (8). pp. 713-721. ISSN 1350-4509

Downloaded from: https://e-space.mmu.ac.uk/621884/

Version: Accepted Version

Publisher: Taylor \& Francis

DOI: https://doi.org/10.1080/13504509.2018.1461707

Please cite the published version 


\section{Planning and Implementing Sustainability in Higher Education Institutions: a overview of the difficulties and potentials}

Leal Filho, W., Pallant, E., . Enete, A., Richter, B., Brandli, L. L. (2018) Planning and

implementing sustainability in higher education institutions: an overview of the

difficulties and potentials. In International Journal of Sustainable Development and

World Ecology. https://doi.org/10.1080/13504509.2018.1461707.

Walter Leal Filho ${ }^{\mathrm{a}}$, Eric Pallant ${ }^{\mathrm{b}}$, Anselm Enete ${ }^{\mathrm{c}}$, Barry Richter ${ }^{\mathrm{d}}$ and Luciana Londero Brandli ${ }^{*}$

"Research and Transfer Centre "Sustainable Development and Climate Change Management", Hamburg University of Applied Sciences, Germany \& School of Science and the Environment, Manchester Metropolitan University, Manchester, UK; ${ }^{b}$ Allegheny College, Meadville, PA, USA; ${ }^{c}$

School for Natural Sciences and Technology for Education, North-West University, South Africa; ${ }^{d}$

*Faculty of Engineering and Architecture, University of Passo Fundo, Brazil.

*corresponding author Walter Leal Filho

\section{Abstract}

Planning in sustainable development is believed to be an important element in allowing higher education institutions to set their goals and to commit themselves towards undertaking concrete actions and measures at all levels in order to implement sustainability. Yet, there is a paucity of research which have looked at the extent to which planning can support institutions of higher education to assess their performances and to determine whether the set aims are being met. This research gap needs to be met so as to allow a better understanding of how planning can help to promote the integration of the three components of sustainable development - economic development, social development and environmental protection in higher education. This paper, an attempt to address this perceived research need, explores the challenges for planning the sustainable development in higher education, also outlining the potentials lessons learned, that can assist in improving Education for Sustainable Development efforts in Higher Education Institutions.

Keywords: planning; higher education; sustainability; international; case studies 


\section{Introduction}

Population and economic growth has resulted in humans consuming the natural resources of the earth at such a rate that the resources have become exhausted or are in danger of being exhausted (World Commission on Environment and Development, 1987). To ensure sustainable environmental development, humans need to accept responsibility for the use of resources in such a manner that biotic systems are conserved for future generations (Mutangadura, 2015; WCED, 1987).

The United Nations Conference on Environment and Development (known as The Earth Summit) held in Rio de Janeiro, Brazil, from 3-14 June 1992 reaffirmed the Declaration of the UN Conference on Human Environment, adopted at Stockholm in 1972. The Agenda for the 21st century, better known as Agenda 21, together with the Rio Declaration on Environment and Development, are two important resulting foundation documents of this conference. Agenda 21 is the contemporary motivation for Environmental Education (EE) and is seen as a comprehensive programme for global action in all areas of Sustainable Development (SD). The Rio Declaration on Environment and Development consists of a series of principles defining the rights and responsibilities of countries (UNEP, 1992). A notable observation of the Earth Summit is that it focuses on the role of Education for Sustainable Development (ESD) as an educational response to the environmental crisis.

The report of the World Commission on Environment and Development (WCED) defines $\mathrm{SD}$ as the type of development that meets the needs of the present without compromising the ability of future generations (WCED, 1987). SD is therefore a process that envisions a desirable 
environment in which living conditions and resource-use continue to meet human needs without undermining the existence of natural biotic systems (Sterling, 2003). In such an environment there needs to be a balance between environmental, social and economic considerations. Attainment of SD therefore requires organizations to constantly seek for equilibrium as regards their interactions with their external environment (Merad et al., 2013). Education plays a pivotal role to ensure the transfer of values, skills, and knowledge to ensure SD. Universities and other higher education (HE) have incorporated SD values and practices in teaching, research, institutional management and operational systems in defining education for the task. The United Nations Environmental Programme emphasizes that "no institutions in modern society are better situated and more obliged to facilitate the transition to a sustainable future than colleges and universities" (Dave et al., 2014, p. 18). Shephard (2007) and Tilbury et al. (2005) add that HE has a particular and specific function, namely to prepare graduates to act as influential citizens who value the United Nations Environmental Programme (UNEP) and appreciate that they have a responsibility to help sustain it.

This paper explores the challenges for planning e sustainable development in higher education, outlining lessons learned that can assist in improving ESD efforts in Higher Education Institutions.

\section{Planning for Sustainable Development in Higher Education}

The higher education sector is one of the most dynamic and competitive sectors. It is influenced by a number of variables at the local, regional, national and international level, and was one of first to react to the challenges of globalization by adopting standardized teaching and degree programmes, such as the Bachelor of Studies, which is now widely used across Europe.

The sector is also heavily influenced by continuous attempts to improve and optimize the 
services it provides to both students and staff, and is constantly involved in means to enhance the delivery of its programmes, be it in respect of teaching, research or extension. Growing competition for the services offered by universities means that planning is essential in order to secure their long term institutional and economic success.

But planning in a higher education context is not a simple task. As stated by Baer, Duin and Ramaley (2008), in many contexts there is a need for "smart change" in order to accommodate the ever changing requirements which surround the higher education business.

Apart from the need for sound planning designs, higher education institutions need iterative approaches, characterized by specific approaches in each sector, which allow them to take preagreed steps and have measureable outcomes. This means that they need to have well designed implementation plans that include the most basic parts of implementation of their strategies, taking into account the need to ensure the availability of the staff time and financial resources needed to achieve the goals that have been set. Table 1 outlines some of the many elements to be considered in fostering planning in a higher education context.

Table 1 - Some elements of planning in a higher education context

\begin{tabular}{l|l}
\hline Item & Relevance \\
\hline Definition of goals & Set-up of priorities \\
\hline Resources management & A more adequate use of resources \\
\hline Inclusiveness & Engaging the various stakeholders \\
\hline Diversity of themes & $\begin{array}{l}\text { Cater for the plurality of topics, courses and programmes on } \\
\text { offer }\end{array}$ \\
\hline Awareness of markets & $\begin{array}{l}\text { Better overview of requirements from the labour market and its } \\
\text { needs }\end{array}$ \\
\hline Analytics & Interpretation of meaningful patterns \\
\hline Consumer satisfaction & Enjoyment of the teaching/learning experience by students/staff \\
\hline
\end{tabular}
Source: authors

The majority of higher education institutions are actively cooperating with industry and 
social partners in their regions, sometimes with companies which have employees they have trained themselves (alumni). The range of services that higher education institutions may offer is quite varied and includes:

- technology transfer

- research support

- market research

- managerial infrastructural guidance

among many others. There is a variety of documents and guidebooks on how to pursue planning in a higher education context (e.g. Hollowell et al., 2006; Hinton, 2012), all of which aim at making of higher education planning a more systematic process, and by doing so, increasing the likelihood of success.

Operationally, many higher education institutions steer their planning by means of specific bodies such as "Strategic Planning Committees" or "Strategic Management Committees" which are bodies created within the organizations to develop, implement and monitor the progress of strategic planning process at the institutional level. The membership of such bodies normally include senior management staff (e.g. Vice-Chancellors, Pro-Vice-Chancellors and Deans), as well as faculty, students and staff representatives.

Since one of the fundamental challenges to higher education institutions is to provide advanced intellectual and practical resources which are adequate to changing professional contexts and to be resilient to political influences, good planning is a pre-condition for institutional success. 
But in order to yield the expected benefits, planning needs to be followed by implementation, evaluation of the measures taken, changes and realization of improvements, as seen in Figure 1. Figure 1.Planning and Improvements Cycle

Source: authors

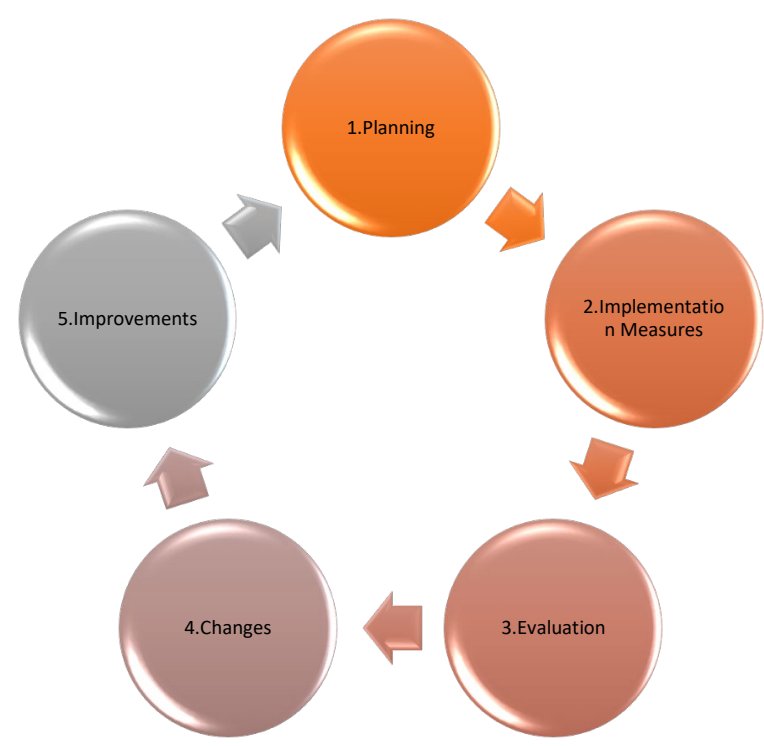

A good understanding of planning processes may be very useful in pursuing sustainable development at higher education institutions, since it provides useful insights into how to seek positive improvements in the quality of the built, natural and historic environment, as well as in people's quality of life, especially in respect of improving the conditions in which people work within a higher education institution, and their lives outside them.

Critically speaking, the design and implementation of plans need to take local circumstances into account. By doing so, they can better respond to the different challenges and take advantage of the many opportunities for achieving sustainable development in different areas, which are available to them. 


\section{Method}

In order to perform this research, cases studies have been developed in five countries: South Africa, Nigeria, United States, Brazil and Germany. The choice of the countries was based on convenience sampling, determined by the knowledge and connection from authors in each context. The choice of universities, constituted a further convenience sample, but also took into account the importance of the universities in the national context, in terms of size, sustainability role and representativeness (Table 2).

Table 2 - Characteristics of the Universities

\begin{tabular}{|c|c|c|c|c|}
\hline University & Country & Established & Students & Website \\
\hline North-West University & South Africa & 2004 & 64.081 & http://www.nwu.ac.za \\
\hline University of Nigeria & Nigeria & 1955 & 36.000 & http://www.unn.edu.ng \\
\hline Allegheny College & United States & 1815 & 1.931 & http://allegheny.edu/ \\
\hline Brasilia University & Brazil & 1962 & 38.475 & http://www.unb.br/ \\
\hline $\begin{array}{l}\text { Hamburg University Of } \\
\text { Applied Sciences }\end{array}$ & Germany & 1970 & 16.800 & $\begin{array}{l}\text { https://www.haw- } \\
\text { hamburg.de/ }\end{array}$ \\
\hline
\end{tabular}

The data were collected using different secondary sources of evidence: website information, documents and literature review data. The analyses of the data has been based on identifying the initiatives and obstacles at these universities and analyzing the evidence of performance of the five areas suggested by UNESCO (2014b): policy to ESD; learning and training environments; building capacities of educators and trainers; empowering and mobilizing youth; sustainable solutions at local level.

Although challenging in terms of different institutional, cultural and other variables involved, collaborative research endeavours like this are important to provide insight into the 
challenges to planning for implementing sustainability in higher education. The findings of the research are qualitative and reveal lessons that can be categorized as goals to assist in planning and a list of obstacles that can serve as cautions for other HEI.

\section{Case Studies: Planning for Implementation of Sustainability in Higher Education}

The Faculty of Education Sciences (Potchefstroom Campus) of the North-West University, South Africa

Plans: To comply with the vision of the Faculty, and to adhere to the priority action areas of the Global Action Programme (UNESCO, 2014a), the subject group Geography Education and Environmental Education embarked on the implementation of teaching and learning, research and service learning in Geography Education and Education for Sustainable Development.

Regarding environmental education and education for sustainability the following initiatives were implemented. North-West University launched a campaign for the inclusion of Environmental Education as a compulsory model in the curriculum of programmes offered in the training of teacher students. Three initial training programmes are involved, namely the Bachelor of Education in the Foundation Phase, the Intermediate Phase, and the Senior and Further Education and Training phases, respectively. The goal is to equip future teachers with the knowledge and capability to implement ESD in the subject(s) they are going to teach. In this way graduates are prepared to act as influential citizens who value their environment and appreciate that they have a responsibility to help sustain it. The knowledge and values regarding ESD that students gain will provide the basis to cement ESD in the lives of children in their classes;

Research projects have been initiated towards establishing Education Management Systems 
(EMS) and ESD in South African schools to help build capacity in these schools. The projects will help to build research capacity in Education for Sustainability among staff members of the subject group. The projects in schools together with the new research initiative dealing with ESD will also help to enhance the goals set by UNEP. All staff members (academic, administrative, maintenance, students etc.) are involved in the establishment of environmental and sustainability awareness. This initiative will also contribute towards the green campus project of the NWU. In addition there are community campaigns to enhance an awareness of environmental and ESD responsibilities.

Obstacles: In SA there are various obstacles to develop sustainable development, the main of which are: the lack of a focus of sustainability in the curriculum of schools; the lack of a specific budget to support the implementation of sustainability in the training of teachers and the difficulties inherent to the mobilization of staff from the various subject groups in the faculty to include sustainability in the subject that they offer. As a result, the Geography Education and Education for Sustainable Development subject group spends substantial amounts of time activating members of staff and making sure all sustainability activities are funded.

\section{The University of Nigeria, Nsukka, Nigeria}

Plans: At the University of Nigeria, Nsukka (UNN), a number of factors combine to drive sustainability plans. Some of these factors may be internal (within the University) or external (outside the University). With regards to internal factors, successive administrations at UNN has strived to ensure sustainability in academic (curriculum and staff development), environment and infrastructure through the establishment of relevant Departments and Centres, each mandated to drive specific areas of sustainability issues. For instance, the University has directorates of academic and physical planning, Center for Environmental Management and Control (CEMAC) and Centre for African Climate Change Adaptation Initiative (ACCAI) with each headed by a 
renowned Professor. The director of academic planning is usually saddled with the responsibility of planning for the sustainability/improvement of academic standards in terms of curriculum, academic staff and research development. Similarly, that of physical planning ensures the maintenance and development of physical infrastructure. CEMAC is a platform for discourse on environmental disasters such as floods, droughts, earthquakes and tsunamis. CEMAC collaborates with the National Emergency Management Agency (NEMA) to organize conferences on environmental issues including climate change. ACCAI is the hub of climate change research in UNN including student and staff (Africa wide) exchange programmes on climate change research. In addition, there are curriculum development committees at the Departmental, Faculty and University levels, such that curriculum development originates from the Department and goes through the Faculty to the University. Similar arrangements are obtainable in most Nigerian Universities perhaps with differences in nomenclature.

Externally, UNN is also under the ambit of the National Universities Commission (NUC), which appraises the programmes (curriculum, staffing, student admission and assessment) of Nigerian Universities from time to time to ensure sustainability of standards. In addition, UNN is covered by the Nigerian government established specialized funding agencies, tailored specifically for the improvement and sustainability of standards in Nigerian tertiary education. These are the Petroleum Technology Development Fund (PTDF) and the Tertiary Education Trust Fund (TeTFund). The PTDF provides human and physical capital maintenance/development, and research and development for technology enhancement for tertiary institutions wholly or partly specialized in training middle and high level manpower for the petroleum industry (PTDF, 2016). The mandate of TeTFund is to administer and disburse the fund in their custody to federal and state tertiary education institutions specifically for the provision and maintenance of the following: 
essential physical infrastructure for teaching and learning, instructional material and equipment, research and publication, academic staff training and development, and any other need, which in the opinion of the board of trustees, is critical and essential for the improvement of quality and maintenance of standards in the higher educational institutions (TeTFund, 2016).

Obstacles: There are a number of challenges bedeviling the picture presented above. These may be internal (within UNN) and/or external (outside UNN) with no hard and fast rule about where one category ends and the other begins, such that some of the factors may appear in both categories. The internal factors include strikes, poor employee motivation, brain drain, corruption, lack of/weak performance assessment methods, curriculum that is poorly adapted to local problems. The external factors include teaching staff shortages, strikes, poor and erratic government funding, policy somersault, corruption (Akubuilo \& Okorie, 2013) and general lack of commitment to the growth of corporate Nigeria.

\section{Allegheny College, United States}

Plans: Allegheny College is a small, liberal arts, undergraduate college located in rural Pennsylvania. The Environmental Science Department at Allegheny College has a rich history of teaching environmental sustainability and promoting a green campus through laboratory work, community involvement, independent study, and collaborative research projects involving students, faculty, staff and administrators (Boulton et al., in press; Eatmon et al., 2015; Pallant et al., 2012). When a combination of bottom-up efforts and top-down leadership converged, a rapid shift towards an integrated sustainability culture took place. Student research, written reports, development of partnerships, dialogue, and the integration of sustainability principles into existing projects and budgets created a comprehensive climate for sustainability (Pallant et al., 2012.)

Allegheny College recognizes its responsibility to pursue sustainability as an integral part of 
its mission. Collaborating with students, faculty, staff, civic leaders, local residents, and other partners, Allegheny develops informed, innovative strategies for sustainability initiatives on campus and in the Meadville community. Most important, Allegheny encourages the development of citizens who actively promote sustainability. Students learn about environmental issues and stewardship at each step of the way, through course work with nationally known faculty and experiential learning opportunities such as internships and volunteering. Student-led organizations complement the curriculum and encourage students to embrace sustainable ways of living and thinking during their time at Allegheny and beyond.

Obstacles: Obstacles to sustainable development are manifold, however. The greatest limitation is available operating budget. Allegheny College has a sustainability coordinator, but she operates largely as a one-person office. Physical Plant and Grounds managers also suffer from budget inadequacies which manifest in insufficient labor available to implement green practices, e.g., installation of water bottle refill stations has been secondary to repairing faltering plumbing; investing in high efficiency boilers and chillers has to wait until sufficient capital is available. An additional impediment to keeping sustainability practices at the forefront of numerous programs, departments, and sections of the college has been the natural rate of turnover in many key positions. Often, when a champion of sustainability departs, it may take his or her replacement many years to join the culture of sustainability. In contrast, some key positions that could be of great assistance to promoting sustainability are occasionally held down for many years by a single indifferent individual.

\section{Brasilia University, Brazil}

Plans: Although many obstacles exist, some Brazilian universities do overcome them. That is the case of Brasilia University (UnB). Since 2008, the UnB has the "UnB Environmental Agenda 
Center" with is supporting and promoting initiatives to promote sustainable actions through the slogan "Show your love to UnB." Professors, students and staff from different academic units compose the center. It aims to interconnect and mobilize the university community, interacting research, teaching and extension, integrating the university activities for a collective and socioenvironmental management in the Campuses of UnB. The results show sustainable answers to the environmental problems, an increase of awareness and the creation of a cooperation network among the UnB campuses (Catalão et al., 2011). Brazil, one of the world's largest developing countries, has a big regional diversity, in terms of culture, economy and climate. At the moment, Brazil has more than 2,400 universities distributed very unequally between their regions, and five to six new institutions open every month. With this fast growth, it is hard for Brazilian government policy to keep up with the pace of higher education expansion, and establish strategies to ensure high quality growth.

Obstacles: An empirical study developed by Brandli et al. (2015) concluded the barriers that universities encounter in implementing sustainability could be at the university level itself, as example of lack of governance for sustainability, lack of institutional program that motivate staff, professors and students to engage in sustainability; lack of interest; lack of knowledge; and overworked professors without time to sustainability actions.

The study also shows the barriers at macro level, or national framework (policy-marking). This level refers to: cultural change; lack of sustainable lifestyle; lack of cooperation networks between universities, lack of government policies to encourage sustainability implementation; lack of resources or available funding for sustainability projects; lack of staff and a senior member of staff who can implement and oversee sustainability efforts, and lack of projects between companies and universities, and R\&D. 


\section{Hamburg University of Applied Sciences, Germany}

Plans: The Hamburg University of Applied Sciences (HAW Hamburg) is, with over 12.000 students, the second largest institution of higher education in the Hamburg region and one of the largest of its kind (University of Applied Sciences) in Germany. Solving current future problems in respect of sustainable development and climate change is one focus of the HAW and therefore different research and transfer centers exist. One of them is Research and Transfer Centre "Sustainable Development and Climate Change Management" (FTZ-NK). The Centre, which coordinates the initiative "Sustainability Lab" (Brandli et al., 2015) and hosts the World Sustainable Development Research and Transfer Centre (WSD-RTC) acts as a testbed for innovative approaches on sustainability as a whole, and on water, energy and climate projects, especially adaptation tools and methods. This is reflected by the various national and international projects on sustainable development and climate change on which the Research and Transfer Centre's team has been working. In addition to the international research and knowledge-transfer projects the FTZ-NK has organized and implemented many international conferences, including the World Symposium on Sustainable Development (WSSD-U) series, hence playing a key role in the national and international sustainability debate.

Obstacles: At HAW Hamburg there are various obstacles to sustainable development, the main of which are: the lack of a specific sustainability policy; the lack of a specific budget to support sustainability efforts, and the difficulties inherent to the mobilization of staff from the various Faculties. As a result, the FTZ-NK team spends substantial amounts of time activating members of staff and making sure all sustainability activities are self-funded. 


\section{Lessons Learned}

The case studies provide a series of lessons that can assist in improving ESD efforts in Higher Education Institutions. The state of the art in the field is as follows:

(1) many universities wish to pursue sustainable development, but their efforts are hindered by lack of institutional support and planning, and limited emphasis on approaches such as problem-based learning (Leal Filho and Davin 2015)

(2) the universities which are engaged in the field, have to face many problems, varying from limited resources, to lack of trained staff (Leal Filho, Paco, Shiel, 2015) and integrated approaches to sustainability become difficult to implement

(3) the many opportunities offered my mainstream developments such as the UN Declaration "The World we Want" (Leal Filho, Manolas, Pace 2015) or the UN Sustainable Development Goals are not being put to full use.

The lessons gathered from the paper can be categorized as goals, in order to assist in planning and a list of obstacles that can serve as cautions for other institutions of HE.

Plans: Key to making planning for and implementing sustainability in HEI is the acquisition of viable plans, sufficient funding to make those plans a reality, and a core group of influential people capable of implementing those plans. Faculty, staff, administrators, and personnel responsible for maintenance and upkeep of grounds and buildings need to be actively seeking new solutions for sustainability and they must be responsible for putting policies in place that will direct activities in purchasing, energy consumption, waste reduction, etc. These policies need to be comprehensive so that when key personnel leave an institution their replacements will be sought for their ability to 
carry out these policies.

Obstacles: At the macro level an important obstacle is connected to a lack of government policy to encourage SD investments and also recognize the results achieved by the universities that do it. At this point, it is important to have a vision of "Education as a Credence Good", recognizing the institutions efforts in sustainability. This could be achieved through rankings such as People \& Planet University League: every UK university that receives public authority funding and is legally registered as a 'Higher Education Institution' is assessed and ranked. (People \& Planet, 2016). There are several comparable rating agencies in the United States and Europe (e.g. STARS, 2015; Sierra Club, 2016; Princeton Review, 2016; Times Higher Education, 2016; UI Green Metric, 2015). Thus, in higher education, the sustainability efforts should have a strong influence on overall institutional reputation, having a considerable impact on the brand value of the undergraduate education. Another important obstacle is the lack of collaboration between universities and national, corporate, and international networks.

Naturally, a key obstacle includes the difficulty of generating reliable upfront capital investment to implement expensive policies and to have continued support of government and administrations even during times of financial uncertainty. In addition, there needs to be a careful assessment of implemented plans to determine both their effectiveness and the satisfaction of endusers. Assessment can be costly and time consuming. Finally, a significant obstacle to the successful implementation of plans in sustainability lies in the area of human resources. Often, the personnel that must promote, implement, and assess plans for sustainability have numerous other responsibilities and their ability to dedicate sufficient time and energy to sustainability projects and policies can be quite taxing. 


\section{Conclusions}

As this paper has tried to demonstrate, planning can be a very useful tool in supporting attempts by institutions of higher education to realize their ambitions to not only integrate the three components of sustainable development in their operations, but to also ensure the principles of sustainability are realized and put into practice. The case studies show three main elements, which are fed into this section:

(1) lack of planning remains a major barrier to be addressed and it can be regarded as a preconditions for universities to successfully implement long term sustainability initiatives;

(2) the integration of the three main components of sustainable development - economic development, social development and environmental protection- in a higher education context need to be holistic and comprehensive (i.e. not limited to a few subjects) so that they become more resilient to both staff and institutional changes. The transformative learning deriving from it will help towards such an integration (Iyer-Raniga, and Andamon 2016);

(3) lack of financial support to sustainability initiatives means that they mostly depend on a few key and committed staff, which in turn puts into question about how durable they may be. Studies have shown that investments in this area are worthy, since a sound financial basis catalyzes the development of more solid skills (World Bank 2012).

As the world now moves towards addressing the challenges posed by Sustainable Development Goals, in the context of which matters such as poverty eradication and changes of unsustainable patterns of production and consumption (among many others) are being pursued, planning may prove a strong ally in offering an environment supportive of internal, but also 
national and international cooperation, particularly in the areas of research and teaching. The work by HAW Hamburg, with the creation of the World Sustainable Development Research and Transfer Centre is in this context a timely one, since there are to date no institutional settings at university level, which may help higher education institutions to address the UN Sustainable Development Goals.

This paper and the case studies it entails has shown that there is a need to build on current thinking related to sustainable development, and to expand it so as to ensure that the obstacles experienced today, may be overcome. Much speaks for this line of thinking. The development of sustainability plans -especially when combined with local and community development- can also act as an enabler to capacity -building, with a special attention to relevant matters of local and global interest, as appropriate.

\section{References}

Akubuilo F, Okorie EU. 2013. Sustainability of Tertiary Education through Quality Assurance and Development in Nigeria. Journal of Education and Practice, 4(15): 140-144.

Baer L, Duin A, Ramaley J. 2008. Smart Change. Planning for Higher Education, 36(2), 5-16.

Boulton K, Pallant E, Wilson C, Choate B, Carbone I (In press). How Allegheny College convinces students to save electricity. International Journal of Sustainability in Higher Education.

Brandli L, Leal Filho WR, Frandoloso MAL, Korf EP, Daris D. 2015. The Environmental Sustainability of Brazilian Universities: Barriers and Pre-conditions. In Leal Filho, W. et al. (Eds.), Integrating Sustainability Thinking in Science and Engineering Curricula (pp. 6374). Berlin: Springer.

Catalão V, Layrargues P, Zaneti I (org). Universidade para o Seculo XXI. Educação Ambiental na Universidade de Brasilia. Brasília:Cidade Gráfica e Editora, 340p.

Dave M, Gou Z, Prasad D, Li F.2014. Greening Universities Toolkit V2.0. Transforming Universities into green and sustainable campuses: A toolkit for implementers. n.p.: UNEP. Retrieved from https://www.researchgate.net/publication/280006863_Greening_Universities_Toolkit_V20_ 
Transforming_Universities_into_Green_and_Sustainable_Campuses_A_Toolkit_for_Imple menters_Advance_Copy

Eatmon T, Pallant E, Laurence S. 2015. Food production as an integrating context for campus sustainability. In Implementing Campus Greening Initiatives (pp 325-336). New York: Springer.

Hinton KE. 2012. A Practical Guide to Strategic Planning in Higher Education Society for College and University Planning. Ann Arbor: Society for College and University Planning.

Hollowell D, Middaugh M, Sibolski E. 2006. Integrating Higher Education Planning and Assessment: A Practical Guide. Ann Arbor: The Society for College and University Planning.

International Union for Conservation of Nature and Natural Resources (IUCN). 1980. Living resource conservation for sustainable development. Gland: IUCN.

Iyer-Raniga U, Andamon M. 2016. Transformative learning: Innovating sustainability education in built environment. International Journal of Sustainability in Higher Education. 17: 105-122.

Leal Filho W, Davin P. (Eds) 2015. Challenges in Higher Education for Sustainability. Springer, Berlin.

Leal Filho W, Manolas E, Pace P. 2015. The future we want. International Journal of Sustainability in Higher Education 16 (1): 112 - 129.

Leal Filho, W, Paco A, Shiel C. 2015. Integrative approaches to environmental sustainability at universities: an overview of challenges and priorities. Journal of Integrative Environmental Sciences, 12 (1):1-14. DOI: 10.1080/1943815X.2014.988273

Lozano R, Lukmanb R, Lozanoc RFJ, Huisingh D, Lambrechts W. 2011. Declarations for sustainability in higher education: becoming better leaders, through addressing the university system. Journal of Cleaner Production, xxx, 1-10.

Merad M, Dechy N, Serir L, Grabisch M, Marcel F. 2013. Using a multi-criteria decision aid methodology to implement sustainable development principles within an organization. European Journal of Operational Research, 224(3): 603-613.

Mutangadura BG. 2015. Sustainable development in Southern Africa: Progress in addressing the challenges. Journal of sustainable development in Africa, 1: 56-69.

Pallant E, Boulton K, McInally D. 2012. Greening the Campus: The Economic Advantages of Research and Dialogue. In W.F. Leal (Ed.), Sustainable Development at Universities: New Horizons (pp. 373-382). Frankfurt: Peter Lang Scientific Publishers.

People \& Planet. 2016. How sustainable is your university? [online] Retrieved from https://peopleandplanet.org/university-league [Accessed 11 Apr. 2016].

Princeton Review 2016. Guide to 361 Green Colleges, 2016. [online] Retrieved from https://www.princetonreview.com/college-rankings/green-guide [Accessed 28 Dec. 2016].

PTDF 2016. PTDF. [online] Retrieved from http://www.ptdf.gov.ng [Accessed 28 Dec. 2016].

Sauvé L. 2005. Currents in environmental education: mapping a complex and evolving pedagogical field. Canadian Journal of Environmental Education, 10: 11-37. 
Shephard K. 2007. Higher education for sustainability: seeking affective learning outcomes. International Journal of Sustainability in Higher Education, 9: 87-98.

Sierra Club 2016. 2016 Cool Schools Full Ranking. Sierra Magazine [online] Retrieved from https://sierraclub.org/sierra/2016-5-september-october/cool-schools-2016/full-ranking [Accessed 30 Dec. 2016].

STARS 2015. STARS Overview. [online] Retrieved from https://stars.aashe.org/pages/about/starsoverview.html [Accessed 28 Dec 2016].

Sterling S. 2003. Whole systems thinking as a basis for paradigm change in education: explorations in the context of sustainability. Ph.D., University of Bath.

TeTFund 2016. Tertiary Education Trust Fund. [online] Retrieved from http://www.tetfund.gov.ng [Accessed 29 Dec. 2016].

Tilbury D, Keogh A, Leighton A, Kent J. 2005. A National Review of Environmental Education and its Contribution to Sustainability in Australia. Canberra: ARIES.

Times Higher Education 2016. World University Rankings. [online] Retrieved from https://www.timeshighereducation.com/world-university-rankings [Accessed 29 Dec. 2016].

UI Green Metric 2015. Overall Ranking 2016. [online] Retrieved from http://greenmetric.ui.ac.id/overall-ranking-2016/ [Accessed 29 Dec. 2016].

UNEP 1992. Rio Declaration on Environment and Development. [online] Rio de Janeiro: United Nations. Retrieved from http://www.unep.org/documents.multilingual/default.asp?documentid=78\&articleid=1163 [Accessed 30 Dec. 2016].

UNESCO 2002. United Nations Report on the World Summit for Sustainable Development Plan of Implementation. Retrieved from http://www.un.org/jsummit/html/documents/summit_docs/2309_planfinal.htm [Accessed 24 Jan. 2012].

UNESCO 2006. Framework for the UNDESD International Implementation Scheme. Retrieved from http://unesdoc.unesco.org/images/0014/001486/148650E.pdf. [Accessed 23 Nov. 2012].

UNESCO 2009. UN decade of education for sustainable development. Retrieved from http://cms01.unesco.org/en/esd/decade-of-esd/ [Accessed 6 Apr. 2009].

UNESCO 2014a. From the Decade of ESD to the Global Action Programme. Retrieved from http://www.unescobkk.org/education/esd/about-esd/ [Accessed 2 Feb. 2016].

UNESCO 2014b. Roadmap for Implementing the Global Action Programme on Education for Sustainable Development. Paris: UNESCO.

UNESCO 2014c. U.N. decade of education for sustainable development: 2005-2014. Retrieved from http://unesdoc.unesco.org/images/0014/001416/141629e.pdf [Accessed 9 Jan 2017].

WCED - see World Commission on Environment and Development

World Bank 2012. Putting Higher Education to Work: Skills and Research for Growth in East Asia (The World Bank East Asia and Pacific Regional Report). Washington, D.C.: The International Bank for Reconstruction and Development / The World Bank. 
World Commission on Environment and Development (1987). From One Earth to One World: An Overview. Oxford: Oxford University Press. 